\title{
A First Assessment of the Cranberry Fruit Rot Complex in Michigan
}

\author{
R. O. Olatinwo, Department of Plant Pathology, Michigan State University, East Lansing 48824; E. J. Hanson, \\ Department of Horticulture, Michigan State University, East Lansing 48824; and A. M. C. Schilder, Department of \\ Plant Pathology, Michigan State University, East Lansing 48824
}

\begin{abstract}
Olatinwo, R. O., Hanson, E. J., and Schilder, A. M. C. 2003. A first assessment of the cranberry fruit rot complex in Michigan. Plant Dis. 87:550-556.

Samples of ripe fruit were taken at harvest from all eight commercial cranberry farms in Michigan over a 3-year period to determine the distribution and incidence of fruit rot diseases and the fungal pathogens associated with rotted fruit. Totals of 23,33 , and 28 beds were sampled in 1999, 2000, and 2001, respectively. Fruit rot incidence varied widely among beds and farms and ranged from 5 to $97 \%$ (mean 33.4\%) in 1999, 1 to $91 \%$ (mean 26.3\%) in 2000, and 1 to $67 \%$ (mean 12.8\%) in 2001. Differences in fruit rot incidence were observed among cultivars, but rankings differed among farms. In general, cultivars Ben Lear, Bergman, and Pilgrim tended to have lower and Beckwith and WSU61 higher fruit rot incidence than other cultivars grown in the same location. Colletotrichum acutatum, Pestalotia vaccinii, and Phyllosticta vaccinii were the fungi most frequently recovered from rotted fruit. Fusicoccum putrefaciens, Phomopsis vaccinii, Physalospora vaccinii, Allantophomopsis lycopodina, Coleophoma empetri, and Botrytis cinerea were isolated occasionally in 1999. The isolation frequency of Physalospora vaccinii, Phomopsis vaccinii, and C. empetri increased markedly in 2000. Glomerella cingulata was first detected in 2001. Fusicoccum putrefaciens was most common in the northern and Glomerella cingulata in the southern growing areas. A comparison of sound and rotted fruit from selected beds showed that Phyllosticta elongata predominated in sound fruit, whereas $G$. cingulata predominated in rotted fruit.
\end{abstract}

Additional keywords: bitter rot, black rot, blotch rot, early rot, end rot, Godronia cassandrae, ripe rot, Vaccinium macrocarpon, viscid rot, yellow rot

Cranberry (Vaccinium macrocarpon Aiton) cultivation was initiated in the early nineteenth century to satisfy an increasing demand for the fruit in both North America and Europe (6). Cranberries are native to Michigan and have been grown there commercially on a small scale for over a century (Fig. 1) (12). As demand for cranberries grew in the early 1990 s, commercial production expanded from 5.6 ha in 1994 to approximately 100 ha in 2000. Therefore, nearly all of Michigan's commercial cranberry acreage is less than 8 years old. Most plantings are situated in the

Corresponding author: R. O. Olatinwo

E-mail: rabiuo@citrus.ucr.edu

Current address of R. O. Olatinwo: Department of Plant Pathology, University of California, Riverside 92521.

American Type Culture Collection (ATCC) accession numbers: Allantophomopsis lycopodina (MYA-1154), Botrytis cinerea (MYA-1158), Coleophoma empetri (MYA-1162), Colletotrichum acutatum (MYA-1159), Fusicoccum putrefaciens (MYA-1155), Pestalotia vaccinii (MYA-1161), Phomopsis vaccinii (MYA-1156), Phyllosticta vaccinii (MYA-1160) and Physalospora vaccinii (MYA-1157).

Accepted for publication 9 January 2003.

Publication no. D-2003-0314-02R

(C) 2003 The American Phytopathological Society "blueberry belt" near the Lake Michigan shore in southwest Michigan. These plantings were established on the acidic, sandy soils typical of blueberry plantings. The sites have natural water tables within 30 to $60 \mathrm{~cm}$ of the surface. Two plantings are located in northern Michigan on sites that may be more typical of many in Wisconsin. Cultivar Stevens accounts for about two-thirds of the acreage, followed by Pilgrim, Le Munyon, Ben Lear, Bergman, Searles, Beckwith, and WSU61 (from Washington State University) (4). Michigan growers have used both plug plants and vines to establish plantings. Since the industry is relatively new, little is known about the diseases that affect cranberries in Michigan.

Fruit diseases vary widely among cranberry-producing states, with cotton ball (Monilinia oxycocci (Woronin) Honey) being a serious disease in Wisconsin (1), and early rot (Phyllosticta vaccinii Earle) and bitter rot (Glomerella cingulata (Stoneman) Spauld. \& H. Schrenk) causing severe losses in Massachusetts (2). In New Jersey, blotch rot (Physalospora vaccinii (Shear) Arx \& E. Müller) and bitter rot ( $G$. cingulata) were the two most common and widely distributed fruit diseases in commercial cranberry beds (11). Cranberry fruit rot is a disease complex involving as many as 32 species of fungi $(6,10)$. Pathogenicity has been established following Koch's postulates for some suspected fruit rot pathogens, such as Physalospora vaccinii (2), Phyllosticta elongata G.J. Weidemann (Botryosphaeria fruit rot and berry speckle), and Phyllosticta vaccinii (13). In the disease complex, the frequency of each fungal species at a given location may vary from year to year or even during the growing season (3).

Nationwide, preharvest and postharvest fruit rots are a major concern because they affect the quality of both fresh-market and processing fruit. Preharvest infection by some pathogens may occur during the growing season and remain latent until fruit ripen (8). Storage rot is a problem in all regions where cranberries are stored under refrigeration before being sold as fresh fruit. While some of the cranberries grown in Michigan are sold fresh, most berries are frozen and then dried or processed for juice. Therefore, field rots are a major concern to the Michigan cranberry industry. This study was conducted to determine the incidence and distribution of fruit rot pathogens in cranberries at harvest as part of a larger project to assess yield constraints and improve pest and disease management practices in commercial cranberry production in Michigan. Preliminary reports of portions of this work have been published $(5,9)$.

\section{MATERIALS AND METHODS}

Sampling, isolation, and identification of fungi. Over a 3-year period, cranberry beds on eight commercial farms in southwest and northeast Michigan, including the Upper Peninsula (UP), were evaluated for fruit diseases (Fig. 1). These farms represented all known commercial cranberry acreage in Michigan. All beds were planted after 1993, except those in the UP, which were originally planted in the late $1800 \mathrm{~s}$. Farm size ranged from one bed to approximately 30 beds, and bed size ranged from 0.2 to 2.5 ha (mean $\sim 1$ ha). Some of the beds were not yet in full production but had enough berries to take the required sample. Fungicide use in each bed was recorded during the 3-year period. Mature fruit was sampled just prior to harvest (from late September to early October) from totals of 23, 33, and 28 commercial cranberry beds in 1999, 2000, and 2001, respectively. Seven cultivars (Pilgrim, Stevens, Ben Lear, Beckwith, Bergman, Searles, and WSU61) were sampled in the 1999 survey. An additional cultivar, Le Munyon, was added in 2000 and 2001. Several farms and beds were not included 
in 2001 because they were temporarily or permanently taken out of production. The South Haven farm was split into two sites (South Haven A and South Haven B), which were approximately $4 \mathrm{~km}$ apart. South Haven B had younger beds than South Haven A. At each farm, 100 berries were collected randomly along a diagonal transect through each bed. Incidence of external fruit rot symptoms was visually determined and recorded. Symptomatic berries were surface-disinfested in $1.5 \%$ $\mathrm{NaOCl}$ for $90 \mathrm{~s}$, rinsed in sterile deionized water twice, and then cut in half transversely. Nonsymptomatic berries were not included. One-half of each berry (the blossom end) was placed with the cut surface down on nonclarified V8 juice agar (160 $\mathrm{ml}$ V8 juice, $3 \mathrm{~g} \mathrm{CaCO}_{3}, 15 \mathrm{~g}$ agar, and $840 \mathrm{ml}$ deionized $\mathrm{H}_{2} \mathrm{O}$ ). The remaining healthy-looking berries in the sample were kept in plastic bags in refrigerated storage at $5^{\circ} \mathrm{C}$ for up to 5 months. Plates were incubated at room temperature (20 to $25^{\circ} \mathrm{C}$ ) and ambient light for 3 to 4 weeks. Fungi were identified directly on the isolation plates by comparing morphological characteristics of the spores and sporebearing structures with descriptions in the literature $(1,10)$. Selected fungal isolates were submitted to the American Type Culture Collection.

Fungal flora of sound and rotted fruit. In 2001, the fungal flora of sound and rotted cranberry fruit was compared in samples from five cranberry beds located in South Haven (farm 6) and Covert (farm 7). The cultivars were Bergman, Stevens, and Pilgrim. Approximately 300 berries per bed were collected just prior to harvest, and each sample was sorted into two categories: sound and rotted. Twenty berries were arbitrarily selected from each of the two categories per bed. Berries were surface-disinfested and processed as previously described.

Data analysis. Data were subjected to analysis of variance using PROC MIXED in SAS (SAS Institute, Cary, NC). A mixed linear model was chosen because the survey design contained both fixed and random effects. The mixed linear model provides appropriate standard errors for all specified estimable linear combinations of fixed and random effects. The farms were grouped into two regions: north (Whitefish Point and Cheboygan) and south (Lawton, Pullman, South Haven A and B, West Olive, Covert, and North Blendon) because of their distinctive climatic conditions. Region was treated as a fixed effect, while farm (nested in region) was treated as a random effect in the model statement. Data on the fungal flora of sound and rotted fruit were subjected to analysis of variance and paired $t$ tests using PROC GLM in SAS.

\section{RESULTS}

Fruit rot incidence. The incidence of rotted cranberries varied widely among beds and farms and ranged from 5 to $97 \%$ (mean $33.4 \%$ ) in 1999,1 to $91 \%$ (mean $26.3 \%$ ) in 2000 , and 1 to $67 \%$ (mean $12.8 \%$ ) in 2001 (Table 1). Overall, the lowest incidence of fruit rot occurred at the northernmost site (Whitefish Point) and the highest incidence at the southernmost site (Lawton) in all 3 years of the study (Table 1). Analysis of variance showed that year, but not region, significantly affected fruit rot incidence (Table 2). There was a significant difference $(\mathrm{P}=0.0002)$ among cultivars (nested in region). Furthermore, the analysis showed a significant interaction effect of year by region on fruit rot incidence (Table 2). Differences in fruit rot incidence among cultivars were apparent in all 3 years, but cultivar ranking differed by farm and, to a lesser extent, by year (Table 1). 'Stevens' was the only cultivar present on all farms, and its ranking also varied by farm and year (Table 1). In general, cultivars Ben Lear, Bergman, and Pilgrim tended to have lower and WSU61 and Beckwith higher fruit rot incidence than other cultivars grown in the same location (Table 1). Fungicide applications varied from none in young plantings to a regular spray program (one to three sprays of mancozeb and/or chlorothalonil between bloom and harvest) in beds in full production. Fruit rot incidence was generally lower in estab- lished cranberry beds with regular fungicide spray programs (Table 1).

Pathogen prevalence. The occurrence of specific pathogens in cranberry beds varied from year to year. In 1999, the predominant fungi isolated from rotted berries were Colletotrichum acutatum (bitter rot) and Phyllosticta vaccinii (early rot) (Fig. 2). Pestalotia vaccinii (Shear) Guba was also frequently isolated. This fungus does not cause a specific disease and is considered a minor fruit-rotting pathogen (1). Other known rot fungi isolated less frequently from rotted cranberry fruit included Allantophomopsis lycopodina (Hohn) Carris (black rot), Fusicoccum putrefaciens Shear (teleomorph: Godronia cassandrae Peck) (end rot), Phomopsis vaccinii Shear (viscid rot), Physalospora vaccinii (blotch rot), Coleophoma empetri (Rostr.) Petr. (ripe rot), and Botrytis cinerea Pers.:Fr. (yellow rot) (Fig. 2). In 1999, black rot was not detected at harvest but developed in some of the samples after cold storage $\left(5^{\circ} \mathrm{C}\right)$ for several months. Allantophomopsis cytisporea (Fr.:Fr.) Petr. and A. lycopodina were isolated from these berries. Other fungi commonly isolated from rotted fruit were species of Alternaria, Epicoccum, Curvularia, Cladosporium, Trichoderma, Phoma, Penicillium, Ceuthospora, and Discosia. Many of these are common saprophytes, and others are of

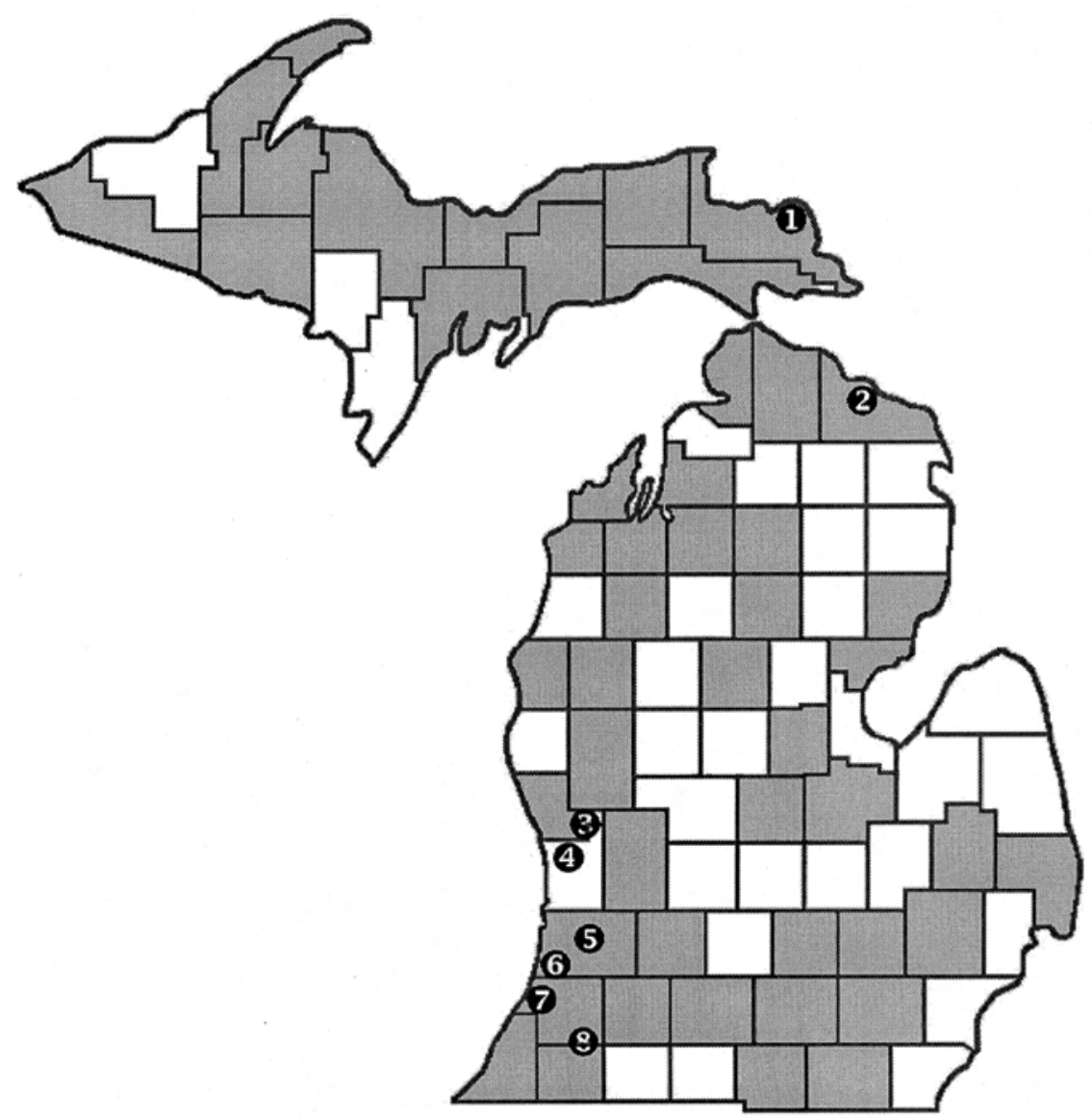

Fig. 1. Location of cranberry farms surveyed for fruit rot in Michigan in 1999 to 2001. Numbers are the same as those in Table 1. Shaded counties contain wild Vaccinium macrocarpon stands (12). 
unknown pathogenicity. In 2000, Colletotrichum acutatum was still the most commonly isolated fungus, but relative isolation frequencies of Physalospora vaccinii, Phomopsis vaccinii, Coleophoma empetri, F. putrefaciens, and $B$. cinerea markedly increased compared with 1999 (Fig. 2). In 2001, Phomopsis vaccinii and Colletotrichum acutatum were the most commonly isolated fungi from fruit with rot symptoms. The incidence of Pestalotia vaccinii was much reduced in 2001 (Fig. 2). Glomerella cingulata, the teleomorph of Colletotrichum gloeosporioides, was first isolated in 2001, primarily in Covert (Table 3 ). This fungus was isolated from all cultivars at this location (Pilgrim, Stevens, and WSU61). Many of these isolates later produced $C$. gloeosporioides conidia in culture. Approximately $20 \%$ of these cultures did not produce perithecia but were still designated as Glomerella cingulata. Over the 3-year period, Fusicoccum putrefaciens was most prevalent at Whitefish Point, but at less than $3 \%$ isolation frequency (Table 3 ).

Colletotrichum acutatum, Pestalotia vaccinii, and Phyllosticta vaccinii were also the most widespread fungal pathogens, occurring in the majority of the cranberry beds in 1999 (Fig. 3). However, in 2000 and 2001, these fungi became progressively less widespread, while the distribution of other fungi, such as Phomopsis vaccinii, Physalospora vaccinii, and $F$. putrefaciens expanded (Fig. 3).

Relative isolation frequencies of pathogens also differed by cultivar, but this may partially be a function of farm location (Table 4). In general, Colletotrichum acutatum, Phyllosticta vaccinii, and Pestalotia vaccinii were isolated from all cultivars (Table 4). Colletotrichum acutatum was particularly common in 'Searles', 'Stevens', and 'WSU61' in 1999. Rotted fruit of 'WSU61' had relatively high isolation frequencies of Pestalotia vaccinii in
1999, Coleophoma empetri in 2000, and Phomopsis vaccinii and Glomerella cingulata in 2001. Physalospora vaccinii was most common in 'Beckwith' and 'Pilgrim' fruit in 2000, and Botrytis cinerea was mostly restricted to 'Searles' in the 3 years (Table 4).

Fungal flora of sound and rotted fruit. The same fungi were detected in rotted and sound fruit, except for Phyllosticta elongata, which was only isolated from sound fruit (Fig. 4). Glomerella cingulata was significantly more common in rotted fruit than in sound fruit. Colletotrichum acutatum, Pestalotia vaccinii, and Phomopsis vaccinii were more frequently recovered from rotted fruit than from sound fruit, but the differences were not statistically significant (Fig. 4).

Table 2. Type III test of fixed effects from mixed-model analysis of fruit rot incidence in commercial cranberry beds in Michigan in 1999 to 2001

\begin{tabular}{lcccc}
\hline Effect & Numerator df & Denominator df $^{\text {a }}$ & $\boldsymbol{F}$ value & $\boldsymbol{P} \boldsymbol{F}$ \\
\hline Region & 1 & 7.2 & 1.50 & 0.2598 \\
Year & 2 & 62.3 & 6.73 & 0.0022 \\
Cultivar (within region) & 8 & 63.1 & 4.51 & 0.0002 \\
Year*region & 2 & 62.3 & 8.41 & 0.0008 \\
\hline
\end{tabular}

${ }^{a}$ Denominator degrees of freedom were calculated using the Satterwaithe approximation.

Table 1. Fruit rot incidence in commercial cranberry beds in Michigan in 1999 to 2001

\begin{tabular}{|c|c|c|c|c|c|c|c|c|c|}
\hline \multirow[b]{2}{*}{ Region } & \multirow[b]{2}{*}{ Farm no. } & \multirow[b]{2}{*}{ Farm location } & \multirow[b]{2}{*}{ Cultivar/bed } & \multicolumn{3}{|c|}{ Fungicide use $^{\mathrm{a}}$} & \multicolumn{3}{|c|}{ Fruit rot incidence $(\%)^{b}$} \\
\hline & & & & 1999 & 2000 & 2001 & 1999 & 2000 & 2001 \\
\hline \multirow[t]{13}{*}{ North } & 1 & Whitefish Point & Searles-1 & $* \mathrm{c}$ & $\mathrm{n}$ & $\mathrm{n}$ & * & 1 & 3 \\
\hline & & & Searles-2 & $*$ & $\mathrm{n}$ & $\mathrm{n}$ & * & 6 & 4 \\
\hline & & & Searles-3 & $*$ & $\mathrm{n}$ & $\mathrm{n}$ & $*$ & 3 & 8 \\
\hline & & & Searles-4 & $\mathrm{n}$ & $\mathrm{n}$ & $\mathrm{n}$ & 30 & 4 & 12 \\
\hline & & & Stevens-1 & $*$ & $\mathrm{n}$ & $\mathrm{n}$ & $*$ & 14 & 18 \\
\hline & & & Stevens-2 & $\mathrm{n}$ & $\mathrm{n}$ & $\mathrm{n}$ & 9 & 8 & 14 \\
\hline & & & Stevens-3 & $*$ & $\mathrm{n}$ & $\mathrm{n}$ & $*$ & 1 & 2 \\
\hline & & & Stevens- 4 & $*$ & $\mathrm{n}$ & $\mathrm{n}$ & $*$ & 8 & 15 \\
\hline & 2 & Cheboygan & Stevens-1 & $\mathrm{y}$ & $\mathrm{y}$ & $\mathrm{y}$ & 39 & 2 & 16 \\
\hline & & & Stevens-2 & $\mathrm{y}$ & $\mathrm{y}$ & $\mathrm{y}$ & 52 & 1 & 20 \\
\hline & & & Stevens-3 & $*$ & $\mathrm{y}$ & $\mathrm{y}$ & $*$ & 7 & 8 \\
\hline & & & Pilgrim & $\mathrm{y}$ & $\mathrm{y}$ & $\mathrm{y}$ & 25 & 1 & 13 \\
\hline & & & Le Munyon & $*$ & $\mathrm{y}$ & $\mathrm{y}$ & $*$ & 22 & 6 \\
\hline \multirow[t]{21}{*}{ South } & 3 & North Blendon & Stevens- 1 & $\mathrm{n}$ & $\mathrm{n}$ & $*$ & 20 & 34 & $*$ \\
\hline & & & Stevens- 2 & $\mathrm{n}$ & $\mathrm{n}$ & $\mathrm{n}$ & 25 & 34 & 6 \\
\hline & 4 & West Olive & Stevens & $\mathrm{y}$ & $\mathrm{y}$ & $\mathrm{y}$ & 32 & 18 & 2 \\
\hline & & & Pilgrim & $\mathrm{y}$ & $\mathrm{y}$ & $\mathrm{y}$ & 12 & 1 & 0 \\
\hline & & & Ben Lear & $\mathrm{y}$ & $\mathrm{y}$ & $\mathrm{y}$ & 14 & 3 & 0 \\
\hline & 5 & Pullman & Stevens & $\mathrm{y}$ & $\mathrm{y}$ & $*$ & 24 & 20 & $*$ \\
\hline & 6 & South Haven A & Beckwith & y & y & $\mathrm{y}$ & 57 & 68 & 35 \\
\hline & & & Stevens ${ }^{\mathrm{d}}$ & $\mathrm{y}$ & $\mathrm{y}$ & $\mathrm{y}$ & 5 & 11 & 2 \\
\hline & & & Pilgrim ${ }^{\mathrm{d}}$ & $\mathrm{y}$ & $\mathrm{y}$ & $\mathrm{y}$ & 19 & 6 & 5 \\
\hline & & & Bergman $^{\mathrm{d}}$ & $\mathrm{y}$ & $\mathrm{y}$ & $\mathrm{y}$ & 6 & 26 & 7 \\
\hline & & & Ben Lear & $\mathrm{y}$ & $\mathrm{y}$ & $\mathrm{y}$ & 9 & 67 & 7 \\
\hline & & & WSU61 & $*$ & $\mathrm{n}$ & $\mathrm{n}$ & $*$ & 77 & 67 \\
\hline & & South Haven B & Stevens & $\mathrm{n}$ & $\mathrm{n}$ & $\mathrm{n}$ & 35 & 47 & 6 \\
\hline & & & Pilgrim & $*$ & $\mathrm{n}$ & $\mathrm{n}$ & $*$ & 43 & 1 \\
\hline & 7 & Covert & Stevens ${ }^{\mathrm{d}}$ & $\mathrm{n}$ & $\mathrm{n}$ & $\mathrm{n}$ & 29 & 6 & 28 \\
\hline & & & Pilgrim $^{\mathrm{d}}$ & $\mathrm{n}$ & $\mathrm{n}$ & $\mathrm{n}$ & 41 & 35 & 29 \\
\hline & & & WSU61 & $\mathrm{n}$ & $\mathrm{n}$ & $\mathrm{n}$ & 43 & 38 & 25 \\
\hline & 8 & Lawton & Pilgrim & $\mathrm{n}$ & $\mathrm{n}$ & $*$ & 50 & 88 & $*$ \\
\hline & & & Stevens-1 & $\mathrm{n}$ & $\mathrm{n}$ & $*$ & 96 & 91 & $*$ \\
\hline & & & Stevens- 2 & $\mathrm{n}$ & $\mathrm{n}$ & $*$ & 97 & 82 & $*$ \\
\hline & & & Average & & & & 33.6 & 26.4 & 12.8 \\
\hline
\end{tabular}

\footnotetext{
${ }^{a}$ Fungicide use: $\mathrm{n}=$ no; $\mathrm{y}=$ yes (one to three sprays of mancozeb and/or chlorothalonil).

${ }^{\mathrm{b}}$ Percentage of a sample of 100 randomly selected berries per bed.

c $*=$ not sampled.

${ }^{\mathrm{d}}$ Beds sampled for study of microflora of sound and rotted fruit.
} 


\section{DISCUSSION}

Fruit rots were very common in cranberry beds in Michigan over the 3 years of this study. In some beds, the majority of the berries were rotted at harvest. A relatively dry summer may have contributed to lower fruit rot levels in 2001. Multiple pathogens were associated with the fruit

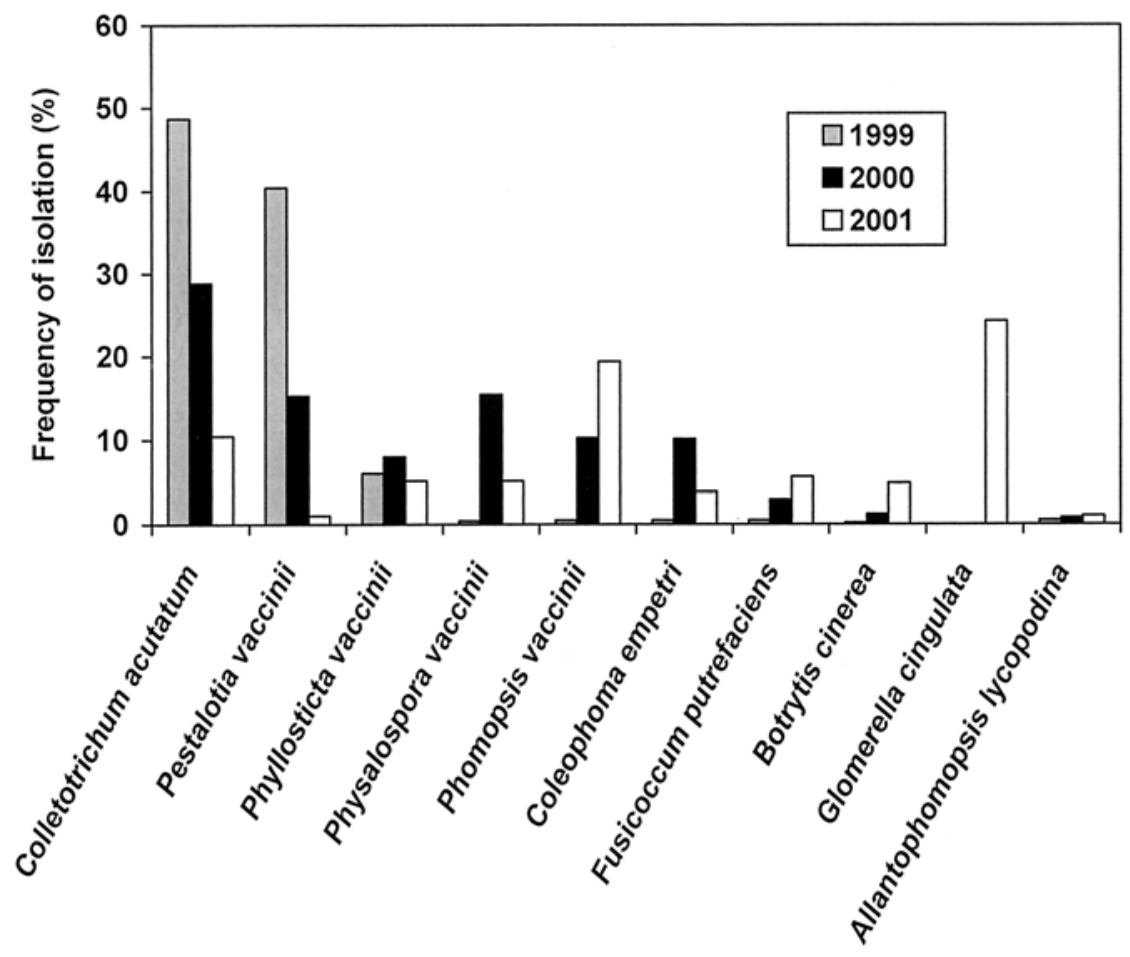

Fig. 2. Relative frequency of isolation of fungi from rotted cranberry fruit in Michigan in 1999 to 2001.

rot complex in Michigan, the most common of which were Colletotrichum acutatum, Pestalotia vaccinii, and Phyllosticta vaccinii. Pestalotia vaccinii is considered a minor pathogen (1). Its role in the fruit rot complex is not clear and merits further investigation. While some symptoms caused by fruit rot fungi can be considered characteristic, it was generally not possible to associate symptoms with specific pathogens or positively identify the rot based only on the appearance of the berry. In addition, over $30 \%$ of the berries hosted more than one fungus. Not all fruit with rot symptoms yielded fungi, indicating that some of the symptoms ( $<5 \%$ overall) may have been due to physiological breakdown or mechanical damage. In some cases, rot may have been secondary to sun scald or insect injury. In young plantings, fruit tended to be more exposed, which may have led to sun scald. However, sun scald injury was not quantified in this study. At one location (Whitefish Point), rot was associated mostly with cranberry fruitworm injury.

Glomerella cingulata (anamorph: Colletotrichum gloeosporioides), while common on cranberries in other parts of the United States $(6,11)$, was detected in 2001 on only a few farms in Michigan (Table 3). In contrast, Colletotrichum acutatum was widespread in Michigan. This species is also the predominant fruit-rotting pathogen in

Table 3. Frequency of isolation of fungi from rotted cranberry fruit by farm location and year (averaged over cultivars and beds) in Michigan in 1999 to 2001

\begin{tabular}{|c|c|c|c|c|c|c|c|c|c|c|c|c|c|c|}
\hline \multirow{2}{*}{$\begin{array}{l}\text { Farm } \\
\text { no. }\end{array}$} & \multirow[b]{2}{*}{ Location } & \multirow[b]{2}{*}{ Year } & \multirow[b]{2}{*}{$\operatorname{Rot}(\%)^{\mathrm{a}}$} & \multicolumn{11}{|c|}{ Isolation frequency $(\%)^{a, b}$} \\
\hline & & & & Coll & Phyl & Pho & Bot & Pes & Phys & Alt & Cole & All & Fus & Glo \\
\hline \multirow[t]{3}{*}{1} & Whitefish Point & 1999 & 19.5 & 5.5 & 2.5 & 0.0 & 1.0 & 4.0 & 0.0 & 6.0 & 0.0 & 0.0 & 2.0 & 0.0 \\
\hline & & 2000 & 5.6 & 0.5 & 0.3 & 0.0 & 0.9 & 0.0 & 0.0 & 0.3 & 0.0 & 0.3 & 1.9 & 0.0 \\
\hline & & 2001 & 9.5 & 0.0 & 0.0 & 0.0 & 2.3 & 0.0 & 0.0 & 0.1 & 0.4 & 0.0 & 2.5 & 0.0 \\
\hline \multirow[t]{3}{*}{2} & Cheboygan & 1999 & 38.7 & 5.8 & 1.8 & 0.7 & 0.0 & 5.8 & 0.0 & 1.4 & 0.0 & 0.0 & 0.0 & 0.0 \\
\hline & & 2000 & 6.6 & 1.0 & 0.2 & 2.2 & 0.0 & 0.4 & 0.2 & 0.2 & 0.0 & 0.2 & 0.0 & 0.0 \\
\hline & & 2001 & 12.6 & 2.6 & 0.8 & 6.6 & 0.0 & 0.0 & 0.0 & 0.2 & 0.4 & 0.0 & 0.4 & 0.0 \\
\hline \multirow[t]{3}{*}{3} & North Blendon & 1999 & 22.5 & 12.0 & 0.5 & 0.0 & 0.0 & 10.5 & 1.0 & 2.0 & 0.0 & 0.0 & 0.0 & 0.0 \\
\hline & & 2000 & 34.0 & 6.5 & 0.0 & 4.5 & 0.0 & 5.5 & 8.5 & 3.0 & 0.0 & 0.0 & 0.5 & 0.0 \\
\hline & & 2001 & 6.0 & 3.0 & 0.0 & 0.0 & 0.0 & 1.0 & 0.0 & 0.0 & 0.0 & 0.0 & 0.0 & 2.0 \\
\hline \multirow[t]{3}{*}{4} & West Olive & 1999 & 19.3 & 12.3 & 1.3 & 0.0 & 0.0 & 6.3 & 0.0 & 0.7 & 0.0 & 0.0 & 0.0 & 0.0 \\
\hline & & 2000 & 7.3 & 3.0 & 1.3 & 1.0 & 0.0 & 0.3 & 0.0 & 0.0 & 0.0 & 0.0 & 0.0 & 0.0 \\
\hline & & 2001 & 0.7 & 0.3 & 0.3 & 0.0 & 0.0 & 0.0 & 0.0 & 0.0 & 0.0 & 0.0 & 0.0 & 0.0 \\
\hline \multirow[t]{3}{*}{5} & Pullman & 1999 & 24.0 & 16.5 & 0.7 & 1.4 & 0.0 & 1.4 & 0.0 & 2.7 & 2.1 & 0.0 & 0.0 & 0.0 \\
\hline & & 2000 & 20.0 & 0.0 & 3.0 & 6.0 & 0.0 & 5.0 & 0.0 & 0.0 & 1.0 & 0.0 & 0.0 & 0.0 \\
\hline & & 2001 & $* \mathrm{c}$ & $*$ & $*$ & $*$ & $*$ & $*$ & $*$ & $*$ & $*$ & $*$ & $*$ & $*$ \\
\hline \multirow[t]{6}{*}{6} & South Haven-A & 1999 & 19.2 & 6.0 & 3.2 & 0.0 & 0.0 & 6.4 & 0.0 & 1.4 & 2.2 & 0.0 & 0.0 & 0.0 \\
\hline & & 2000 & 42.5 & 3.8 & 4.2 & 3.7 & 0.0 & 3.3 & 3.3 & 1.0 & 8.7 & 0.5 & 0.0 & 0.0 \\
\hline & & 2001 & 20.5 & 3.3 & 2.7 & 6.5 & 0.2 & 0.3 & 3.3 & 1.2 & 2.3 & 0.5 & 0.0 & 0.0 \\
\hline & South Haven-B & 1999 & 35.0 & 21.0 & 2.0 & 0.0 & 0.0 & 0.0 & 0.0 & 1.0 & 0.0 & 0.0 & 0.0 & 0.0 \\
\hline & & 2000 & 45.0 & 25.5 & 1.0 & 3.0 & 0.0 & 11.5 & 1.0 & 0.0 & 0.0 & 0.0 & 0.0 & 0.0 \\
\hline & & 2001 & 3.5 & 1.0 & 0.0 & 0.0 & 0.0 & 0.0 & 0.0 & 0.0 & 0.0 & 0.0 & 0.0 & 2.5 \\
\hline \multirow[t]{3}{*}{7} & Covert & 1999 & 37.7 & 16.0 & 0.0 & 0.0 & 0.0 & 22.3 & 0.0 & 1.0 & 0.0 & 0.0 & 0.0 & 0.0 \\
\hline & & 2000 & 26.3 & 10.1 & 3.0 & 0.0 & 0.3 & 4.4 & 1.0 & 0.0 & 0.0 & 0.0 & 0.7 & 0.0 \\
\hline & & 2001 & 27.3 & 0.7 & 0.0 & 0.0 & 0.0 & 0.0 & 0.0 & 0.0 & 0.0 & 0.0 & 0.0 & 25.3 \\
\hline \multirow[t]{3}{*}{8} & Lawton & 1999 & 81.0 & 41.3 & 1.0 & 0.0 & 0.0 & 16.4 & 0.6 & 1.0 & 0.3 & 0.0 & 0.0 & 0.0 \\
\hline & & 2000 & 87.0 & 19.7 & 5.3 & 3.0 & 0.0 & 9.0 & 25.0 & 1.0 & 2.0 & 0.0 & 0.7 & 0.0 \\
\hline & & 2001 & $*$ & $*$ & $*$ & $*$ & $*$ & $*$ & $*$ & $*$ & $*$ & $*$ & $*$ & $*$ \\
\hline
\end{tabular}

${ }^{\text {a }}$ Percentage based on original sample of 100 berries.

${ }^{\mathrm{b}}$ Species: Coll = Colletotrichum acutatum, Phyl $=$ Phyllosticta vaccinii, $\mathrm{Pho}=$ Phomopsis vaccinii, Bot $=$ Botrytis cinerea, Pes $=$ Pestalotia vaccinii, Phys

$=$ Physalospora vaccinii, Alt $=$ Alternaria sp., Cole $=$ Coleophoma empetri, All $=$ Allantophomopsis lycopodina , Fus $=$ Fusicoccum putrefaciens, and Glo = Glomerella cingulata

$\mathrm{c} *$ not sampled. 
Michigan blueberries, which are grown in the same general areas as cranberries (8). The climate in Michigan may be particularly suitable for this pathogen, or cranberry isolates may have originated on blueberries. More research is needed to investigate the latter hypothesis. No perithecia were detected in cultures of $C$. acutatum during the 3 years of this study.

Differences in fruit rot incidence among cultivars may reflect host plant resistance (6). In a survey in New Jersey, cultivars Early Black and Stevens were found to be infected by all major fungal pathogens,

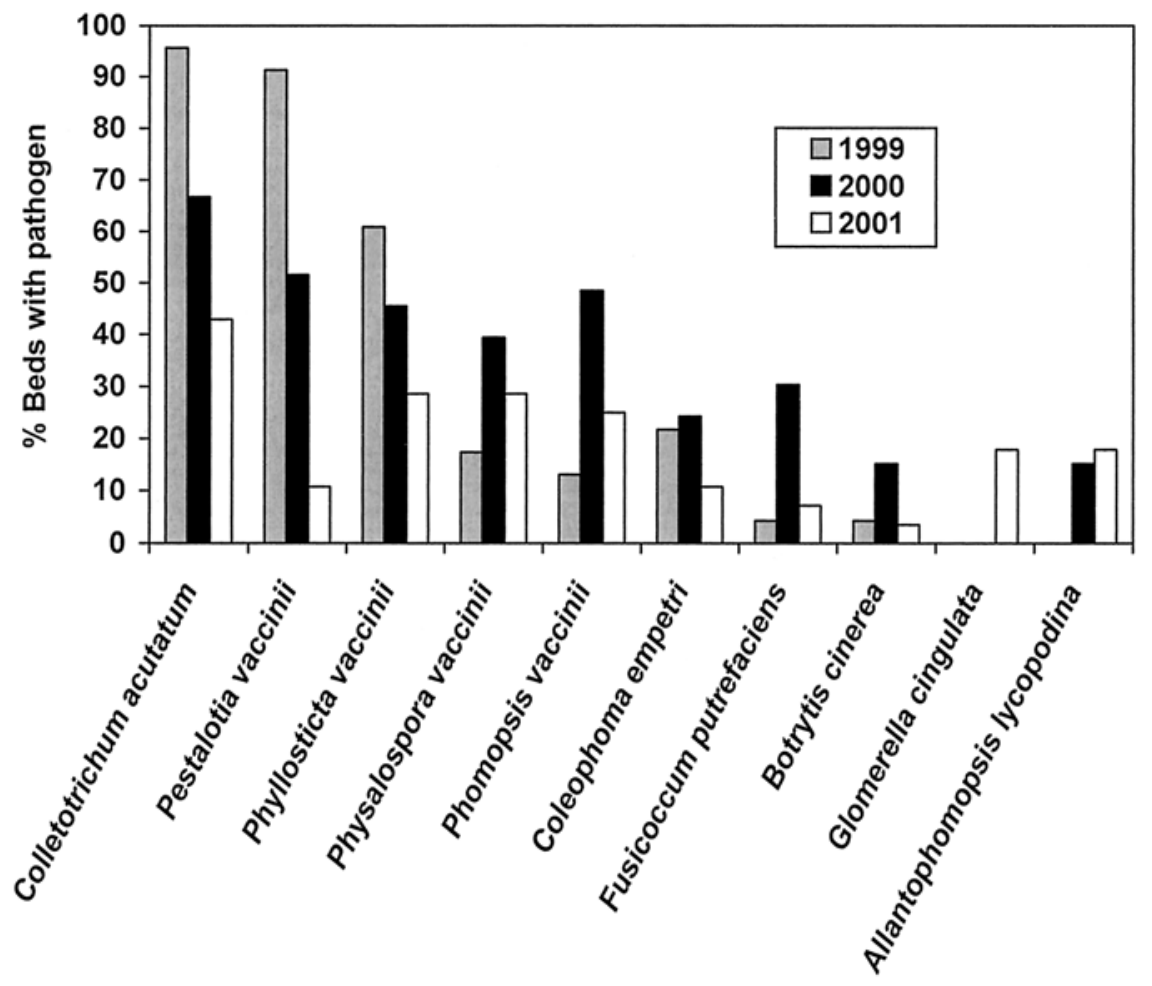

Fig. 3. Percentage of cranberry beds with specific fruit-rotting fungi in Michigan in 1999 to 2001.

including Physalospora vaccinii, Glomerella cingulata, and Phomopsis vaccinii (11). Cultivar differences in susceptibility were difficult to assess in our study, since not all cultivars were present in all locations and cultivar ranking changed with location. The change in rank may be related to differences in pathogen prevalence and environmental conditions among sites. Pathogen prevalence varied by farm location. For example, Physalospora vaccinii was very common in Lawton and North Blendon, while $F$. putrefaciens was found mostly in beds at Whitefish Point, UP. $F$. putrefaciens is known to cause a rot in cranberries held in refrigerated storage (10), but it is also a serious canker pathogen of highbush blueberries in the UP of Michigan (7). Most cranberry fruit rot fungi grow very slowly below $10^{\circ} \mathrm{C}$ with the notable exception of $F$. putrefaciens, suggesting that it is adapted to cold climates (1).

Cotton ball, a common disease of cranberries in Wisconsin, was rare in Michigan and primarily restricted to the farm in Whitefish Point, UP, where 2 to $3 \%$ of the berries were infected. This may be related to the advanced age of the beds or the inadvertent introduction of cotton ball sclerotia with vines from Wisconsin that were used to plant the beds. Climate may also play a role, since the climatic conditions in the UP more closely resemble those in Wisconsin than in Southwest Michigan. In the United States, cotton ball is only economically important in Wisconsin and does not occur in Massachusetts or New Jersey,

Table 4. Frequency of isolation of fungi from rotted cranberry fruit by cultivar and year (averaged over locations and beds) in Michigan in 1999 to 2001

\begin{tabular}{|c|c|c|c|c|c|c|c|c|c|c|c|c|c|}
\hline \multirow[b]{2}{*}{ Cultivar } & \multirow[b]{2}{*}{ Year } & \multirow[b]{2}{*}{$\operatorname{Rot}(\%)^{\mathrm{a}}$} & \multicolumn{11}{|c|}{ Isolation frequency $(\%)^{\mathrm{a}, \mathrm{b}}$} \\
\hline & & & Coll & Phyl & Pho & Bot & Pes & Phys & Alt & Cole & All & Fus & Glo \\
\hline \multirow[t]{3}{*}{ Beckwith } & 1999 & 57.0 & 8.0 & 3.0 & 0.0 & 0.0 & 9.0 & 0.0 & 2.0 & 5.0 & 0.0 & 0.0 & 0.0 \\
\hline & 2000 & 68.0 & 3.0 & 6.0 & 3.0 & 0.0 & 2.0 & 11.0 & 0.0 & 5.0 & 2.0 & 0.0 & 0.0 \\
\hline & 2001 & 35.0 & 0.3 & 2.2 & 1.1 & 0.0 & 0.0 & 4.9 & 0.8 & 1.1 & 0.3 & 0.0 & 0.0 \\
\hline \multirow[t]{3}{*}{ Ben Lear } & 1999 & 11.5 & 7.5 & 4.5 & 0.0 & 0.0 & 1.5 & 0.0 & 0.0 & 2.5 & 0.0 & 0.0 & 0.0 \\
\hline & 2000 & 35.0 & 3.5 & 3.0 & 1.5 & 0.0 & 7.5 & 1.0 & 0.5 & 0.0 & 0.5 & 0.0 & 0.0 \\
\hline & 2001 & 3.5 & 0.5 & 0.0 & 0.0 & 0.0 & 0.0 & 0.5 & 1.5 & 0.0 & 0.0 & 0.0 & 0.0 \\
\hline \multirow[t]{3}{*}{ Bergman } & 1999 & 6.0 & 2.0 & 1.0 & 0.0 & 0.0 & 5.0 & 0.0 & 0.0 & 1.0 & 0.0 & 0.0 & 0.0 \\
\hline & 2000 & 26.0 & 1.0 & 5.0 & 8.0 & 0.0 & 1.0 & 4.0 & 1.0 & 3.0 & 0.0 & 0.0 & 0.0 \\
\hline & 2001 & 7.0 & 0.0 & 4.0 & 4.0 & 0.0 & 1.0 & 0.0 & 0.0 & 0.0 & 0.0 & 0.0 & 0.0 \\
\hline \multirow[t]{3}{*}{ Le Munyon } & 1999 & $* \mathrm{c}$ & $*$ & $*$ & $*$ & $*$ & $*$ & $*$ & $*$ & $*$ & $*$ & $*$ & $*$ \\
\hline & 2000 & 22.0 & 3.0 & 1.0 & 7.0 & 0.0 & 2.0 & 0.0 & 1.0 & 0.0 & 0.0 & 0.0 & 0.0 \\
\hline & 2001 & 6.0 & 0.0 & 1.0 & 6.0 & 0.0 & 0.0 & 0.0 & 1.0 & 0.0 & 0.0 & 0.0 & 0.0 \\
\hline \multirow[t]{3}{*}{ Pilgrim } & 1999 & 30.3 & 11.0 & 1.5 & 0.2 & 0.0 & 11.3 & 0.0 & 0.2 & 0.0 & 0.0 & 0.0 & 0.0 \\
\hline & 2000 & 29.0 & 11.7 & 0.7 & 0.2 & 0.2 & 5.0 & 8.8 & 0.3 & 0.7 & 0.0 & 0.5 & 0.0 \\
\hline & 2001 & 9.6 & 2.8 & 0.2 & 0.4 & 0.2 & 0.0 & 0.0 & 0.0 & 0.0 & 0.0 & 0.0 & 5.4 \\
\hline \multirow[t]{3}{*}{ Searles } & 1999 & 30.0 & 11.0 & 5.0 & 0.0 & 2.0 & 8.0 & 0.0 & 12.0 & 0.0 & 0.0 & 4.0 & 0.0 \\
\hline & 2000 & 3.5 & 1.0 & 0.0 & 0.0 & 1.5 & 0.0 & 0.0 & 0.0 & 0.0 & 0.2 & 1.2 & 0.0 \\
\hline & 2001 & 6.8 & 0.0 & 0.0 & 0.0 & 1.3 & 0.0 & 0.0 & 0.0 & 0.5 & 0.0 & 1.5 & 0.0 \\
\hline \multirow[t]{3}{*}{ Stevens } & 1999 & 38.9 & 21.8 & 1.7 & 0.0 & 0.0 & 11.0 & 0.4 & 2.6 & 0.4 & 0.0 & 0.0 & 0.0 \\
\hline & 2000 & 24.0 & 6.3 & 1.6 & 2.3 & 0.1 & 2.8 & 2.6 & 0.8 & 0.4 & 0.1 & 0.7 & 0.0 \\
\hline & 2001 & 11.4 & 0.9 & 0.3 & 2.3 & 1.1 & 0.1 & 0.1 & 0.1 & 0.3 & 0.0 & 1.3 & 2.9 \\
\hline \multirow[t]{3}{*}{ WSU61 } & 1999 & 43.0 & 22.0 & 0.0 & 0.0 & 0.0 & 29.0 & 0.0 & 3.0 & 0.0 & 0.0 & 0.0 & 0.0 \\
\hline & 2000 & 57.5 & 2.5 & 7.5 & 4.0 & 0.0 & 4.0 & 3.0 & 0.0 & 20.0 & 0.0 & 0.0 & 0.0 \\
\hline & 2001 & 46.0 & 7.0 & 1.5 & 15.5 & 0.0 & 0.5 & 0.0 & 0.5 & 5.0 & 0.0 & 0.0 & 10.5 \\
\hline
\end{tabular}

a Percentage based on original sample of 100 berries.

b Species: Coll = Colletotrichum acutatum, Phyl = Phyllosticta vaccinii, Pho = Phomopsis vaccinii, Bot = Botrytis cinerea, Pes = Pestalotia vaccinii, Phys $=$ Physalospora vaccinii, Alt = Alternaria sp., Cole = Coleophoma empetri, All = Allantophomopsis lycopodina, Fus = Fusicoccum putrefaciens, and Glo = Glomerella cingulata .

c * not sampled. 
despite the presence of susceptible varieties (1).

All the major fruit rot pathogens found in other cranberry-growing regions of the United States were observed in Michigan, albeit at different frequencies. In general, the cranberry fruit rot complex in Michigan appears to be similar to that in the that this has as much to do with climatic conditions as with origin of the planting material. Distribution of vines and cuttings may have resulted in movement of different species of fruit rot fungi (6). Growers in Michigan have obtained planting material from various locations, including Wisconsin and New Jersey. Most beds were planted with rooted cuttings, and some were planted with vines. Both could have carried pathogens in leaves, stems, and fruit remnants. This may explain the surprising variety of fungal pathogens found even in young cranberry beds. Another potential source of pathogens may be wild cranberries, since native populations of $V$. macrocarpon are present in the same geographical areas as cultivated cranberries (Fig. 1) (12). Coleophoma empetri fruit rot was found in approximately $12 \%$ of the berries in a wild stand of Vaccinium macrocarpon near South Haven, MI. (A. M. C. Schilder and R. O. Olatinwo, unpublished). Berries from a wild stand of $V$. oxycoccus L. (small cranberry) near Newberry (UP) yielded a species of Eupenicillium, which was not detected in cultivated cranberries in this study. Neither wild stand appeared northeastern United States (6). We suspect

to harbor cotton ball disease (A. M. C. Schilder and R. O. Olatinwo, unpublished). While cultivated and wild stands of cranberries are usually spatially separated, some commercial cranberry beds were established in wetland areas that probably contained wild cranberries before clearing, opening up the possibility of disease spread from wild to cultivated berries. In addition, some cranberry pathogens may have spread from cultivated blueberries (Vaccinium corymbosum L.), as some commercial cranberry beds are situated next to blueberry plantings.

The fungal flora of healthy-looking cranberries was surprisingly similar to that of rotted berries in the same bed, suggesting latent infections. However, G. cingulata predominated in rotted fruit, whereas Phyllosticta elongata predominated in sound fruit. These findings are consistent with a similar study conducted over a 2year period in New Jersey (11), although additional fungi were isolated in New Jersey. In our survey, Phyllosticta elongata was rarely isolated from rotted fruit at harvest, corroborating findings by Shear et al. (10) that showed this fungus to be a relatively minor fruit rot pathogen in the field but a more prevalent one in storage. Phyllosticta elongata is also associated with latent infections in cranberry leaves and fruit and causes a berry speckle (13). Re-evaluation of fruit left over from the experiment indicated the presence of yellow speckles on berries previously identified as sound. These speckles may

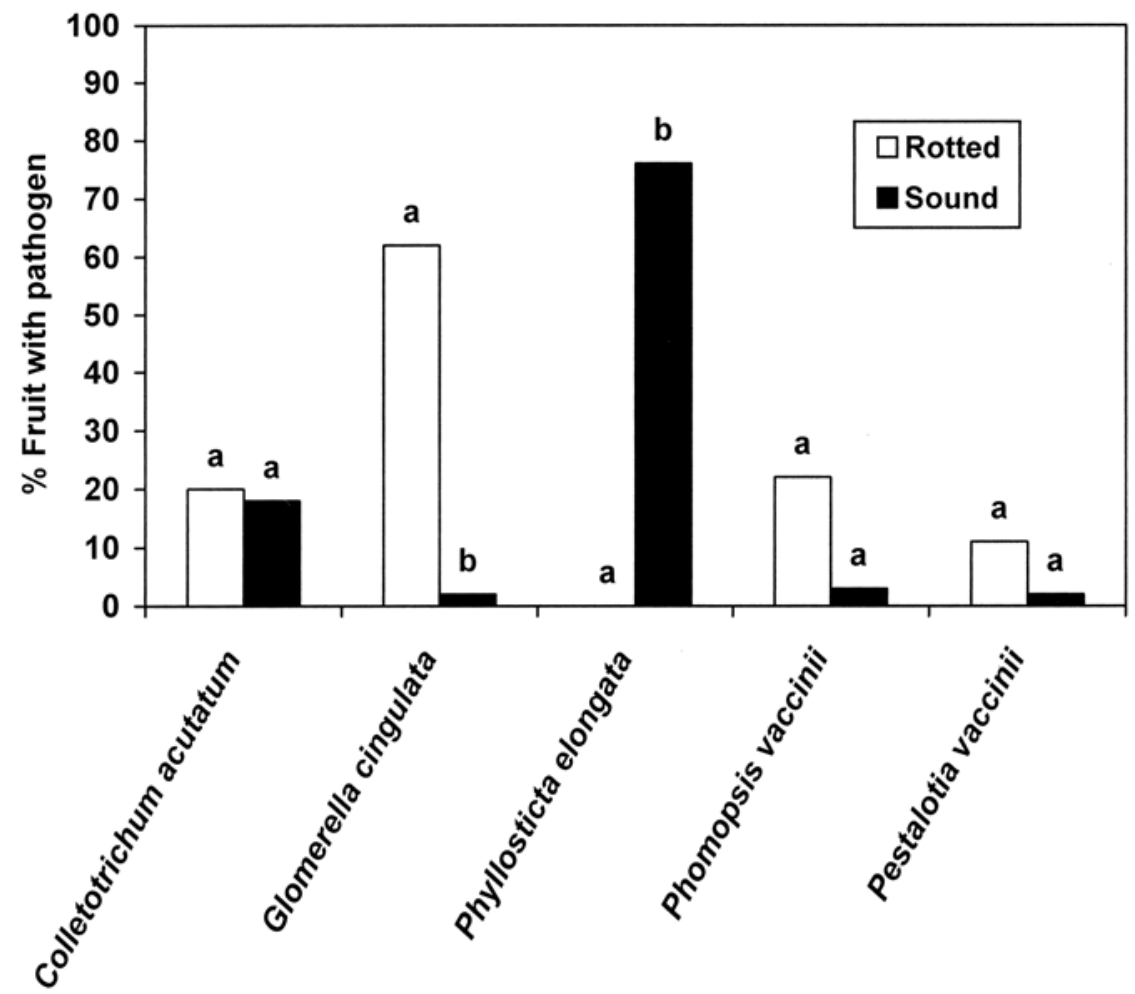

Fig. 4. Comparative isolation frequency of fungi from sound and rotted fruit in five commercial cranberry beds in 2001 . For each pathogen, bars with the same letters are not significantly different from each other according to a paired $t$ test $(P<0.05)$. have been caused by Phyllosticta elongata.

The distribution and incidence of cranberry fruit rots in Michigan are likely to change as the cranberry beds age. Cranberry plantings are relatively young in Michigan compared to other cranberrygrowing regions of the United States. We speculate that the cranberry fruit rot complex will become even more diverse over time, and that the incidence of other diseases, such as upright dieback caused by Phomopsis vaccinii, will increase. Studies in New Jersey also show that the cranberry fruit rot complex is dynamic (11). Different fungal species predominate at different locations, and the frequencies can vary greatly among years.

Information from this study will help in specifying disease control recommendations for cranberry beds in Michigan. Considering the economic malaise that currently plagues cranberry production in the United States and the world, it is even more critical that crop protection resources are used efficiently. Information on efficacy and optimum application timing of currently registered and new fungicides, and their effects on specific fruit rot pathogens, will be needed to design more efficient cranberry disease management strategies in the future.

\section{ACKNOWLEDGMENTS}

We thank the Michigan cranberry growers who kindly allowed us to sample fruit from their farms. We thank Steven Berkheimer, Sally Esman, and Bill Schneider for assistance in collecting fruit. We also thank Fernando Cardoso for statistical assistance. The study was supported in part by the Michigan Cranberry Council and by the GREEEN Project (Generating Research and Extension to meet Economic and Environmental Needs) at Michigan State University. Finally, we thank the Michigan Agricultural Experiment Station for supporting this research.

\section{LITERATURE CITED}

1. Caruso, F. L., and Ramsdell, D. C., eds. 1995. Compendium of Blueberry and Cranberry Diseases. American Phytopathological Society, St. Paul, MN.

2. Eck, P. 1990. The American Cranberry. Rutgers University Press, New Brunswick, NJ.

3. Jeffers, S. N. 1991. Seasonal incidence of fungi in symptomless cranberry leaves and fruit treated with fungicides during bloom. Phytopathology 81:636-644.

4. Kleweno, D. D., and Matthews, V. 2001. Fruit Inventory 2000-2001. Michigan Rotational Survey. Michigan Agricultural Statistics Service, Michigan Department of Agriculture, Lansing.

5. Olatinwo, R. O., and Schilder, A. M. C. 2000. Incidence of fruit-rotting fungi in commercial cranberry beds in Michigan in 1999. (Abstr.) Phytopathology 90:S57.

6. Oudemans, P. V., Caruso, F. L., and Stretch, A. W. 1998. Cranberry fruit rot in the northeast: A complex disease. Plant Dis. 82:1176-1184.

7. Ramsdell, D. C. 1996. Blueberry Diseases in Michigan. MSU AG Facts. Ext. Bull. E-1731.

8. Schilder, A. M. C., and Gillett, J. M. 1999. Prevalence of fruit rotting fungi in blueberry fields in Michigan. (Abstr.) Phytopathology 89:S69.

9. Schilder, A. M. C., Olatinwo, R. O., and 
Hanson, E. J. 2002. Fruit rots are common in commercial cranberry beds in Michigan, U.S.A. Acta Hortic. (ISHS) 574:91-93.

10. Shear, C. L., Stevens, N. E., and Bain, H. F. 1931. Fungous diseases of the cultivated cranberry. U.S. Dep. Agric. Tech. Bull. 258.
11. Stiles, C. M., and Oudemans, P. V. 1999. Distribution of cranberry fruit-rotting fungi in New Jersey and evidence for nonspecific host resistance. Phytopathology 89:218-225

12. Voss, E. G. 1996. Michigan Flora, Part III, Dicots (Pyrolaceae-Compositae). Cranbrook
Institute of Science and University of Michigan Herbarium, Bloomfield Hills, MI.

13. Weideman, G. J., and Boone, D. M. 1982 Taxonomy of Phyllosticta vaccinii (Coelomycetes) and a new name for the true anamorph of Botryosphaeria vaccinii (Dothideales, Dothioraceae). Mycologia 74:59-65. 